\title{
Molecular evidence that the proliferative kidney disease organism unknown (PKX) is a myxosporean*
}

\author{
Denis Saulnier ${ }^{1, * *}$, Hervé Philippe ${ }^{2}$, Pierre de Kinkelin ${ }^{1}$ \\ ${ }^{1}$ Unité de Virologie et Immunologie Moléculaires, Pathologie infectieuse et Immunité des Poissons, INRA, \\ F-78362 Jouy-en-Josas cedex, France \\ ${ }^{2}$ Laboratoire de Biologie Cellulaire, Bâtiment 444, Université Paris-Sud, F-91415 Orsay cedex, France
}

\begin{abstract}
The proliferative kidney organism unknown ( $\mathrm{PKX}$ ), a serious salmonid fish pathogen, is considered to be a myxosporean on the basis of ultrastructural studies, but its real taxonomic position has never been confirmed. In order to ascertain its position, genomic DNA was extracted from PKX and small subunit (SSU) ribosomal DNA was amplified by PCR, cloned and sequenced. A phylogenetical analysis on SSU rDNA from 76 or 128 eucaryotic species was carried out. Whatever the tree reconstruction methods used, PKX was found to be a sister group of the Myxozoa phylum, providing the first molecular evidence for its membership in this phylum.
\end{abstract}

KEY WORDS: Myxozoan - Myxosporeans $\cdot$ PKX - Small subunit rDNA sequence $\cdot$ Molecular phylogeny

\section{INTRODUCTION}

The parasite designated 'proliferative kidney organism unknown' (PKX) (Ferguson \& Adair 1977) has been jeopardizing salmonid fish farming industry in Europe for more than 2 decades but it still remains poorly understood (Hedrick et al. 1993). PKX induces proliferative kidney disease (PKD), which is not directly transmissible from diseased to healthy salmonid fish except by injection (D'Silva et al. 1984), and its life cycle remains unknown to date.

In contrast, the morphology and ultrastructure of this parasite in fish tissues have been widely studied (Kent \& Hedrick 1985). The developmental stages of PKX in kidney interstitium share structural features with the presporogonic stages of organisms belonging to the phylum Myxozoa (Kent \& Hedrick 1985). In spite of their multicellularity, implying cellular differentiation,

\footnotetext{
- Nucleotide sequence data reported in this paper are available in the GenBank ${ }^{T M}$ databases under the accession number U70623

- Present address: Laboratoire d'Aquaculture Tropicale, Centre Océanologique du Pacifique, IFREMER, BP 7004, 98719 Taravao, Tahiti, French Polynesia.

E-mail: dsaulnie@ifremer.fr
}

myxosporean parasites are usually assigned to the Protozoa because of the absence of typical metazoan gametes during sporogenesis. These observations led to the proposal to shift them to a phyletic level distinct from the Metazoa (Grassé \& Lavette 1978). Recently, the sequence analysis of several myxosporean genes encoding small subunit (SSU) rRNA revealed that these parasites belonged to the Metazoa, either to the Nematoda (Smothers et al. 1994) or to the Cnidaria (Sidall et al. 1995).

Since the classification of myxosporeans is based upon the characteristics of their mature spores (Lom \& Arthur 1989), the real taxonomic position of PKX has never been definitely confirmed insofar as very few immature spores have been found in kidney tubules of diseased fish. Furthermore mixed infections could have occurred. Finally, some electron-dense bodies or 'haplosporosomes' have been found within the primary cell of PKX, which suggested similarities with organisms belonging to the phylum Ascetospora, rendering the precise taxonomic status of this parasite questionable (Ferguson \& Needham 1978, Seagrave et al. 1980).

In this report, we present the results of sequencing of the PKX gene encoding the SSU rRNA which place PKX next to the myxosporeans. 


\section{MATERIALS AND METHODS}

Parasites and DNA extraction. Parasitic PKX cells were raised from rainbow trout Oncorhynchus mykiss held at $16^{\circ} \mathrm{C}$ and intraperitoneally injected with a cell suspension. from PKX-infected kidney tissue (D'Silva et al. 1984). Genomic DNA from enriched PKX cells (EPKC) (Saulnier \& de Kinkelin 1996) was prepared using a standard SDS/proteinase $\mathrm{K}$ digestion followed by chloroform/phenol extraction (Jackson et al. 1991).

Cloning and sequencing of PKX SSU rRNA gene. The SSU rRNA gene was amplified by polymerase chain reaction (PCR) from EPKC genomic DNA with the use of the universal primers for eukaryotic $16 \mathrm{~S}$-like rDNA (Medlin et al. 1988). The coding strand primer and the reverse primer were respectively flanked at the 5' end with EcoRI and XhOI cloning restriction sites. PCR reaction mixtures contained reaction buffer (10 mM Tris- $\mathrm{HCl}, \mathrm{pH} 9.0,50 \mathrm{mM} \mathrm{KCl}, 1.5 \mathrm{mM} \mathrm{MgCl}_{2}$, $0.1 \%$ Triton $\mathrm{X}-100), 250 \mathrm{nM}$ of each primer, $200 \mu \mathrm{M}$ each of dATP, dCTP, dGTP, dTTP (Pharmacia), and template DNA in a volume of $100 \mu l$. The samples were preheated at $94^{\circ} \mathrm{C}$ for $5 \mathrm{~min}$ to denature DNA, then immediately cooled on ice. 2.5 units of Taq polymerase (Promega) was then added and after brief vortexing, samples were overlaid with mineral oil. The reaction mixtures were cycled in a DNA Thermal Cycler (MJ Research) 35 times at $94^{\circ} \mathrm{C}$ for 1 min, $45^{\circ} \mathrm{C}$ for $2 \mathrm{~min}$ and $72^{\circ} \mathrm{C}$ for $3 \mathrm{~min}$ with a final extension at $72^{\circ} \mathrm{C}$ for 5 min. Restriction mapping of the PCR amplification product revealed a Xhol restriction site situated $264 \mathrm{bp}$ upstream from the 3 ' terminus. The EcoRI and Xhol digested PCR fragment was purified on low melting point agarose and ligated into EcoRI/XhoI-cleaved pBluescript plasmid using T4-ligase enzyme. Escherichia coli TGi cells that had been transformed were screened by restriction endonuclease analysis.

DNA sequencing. Both strands of the clones containing rDNA inserts were sequenced using a T3 and T7 dye primer sequencing kit (U.S. Biochemical) and subsequent sequences were obtained by priming with specific synthetic oligonucleotides (Eurogentec) deduced from the rDNA sequence. The entire 3 ' end coding strand from the amplification product obtained with universal primers was sequenced using a quick PCR purification kit (Qiagen) and synthetized primers. Automated sequencing was performed on an Applied Biosystem, 383a automated DNA sequencer (McCombie et al. 1992) and sequence data were analysed using the Genetics Computer Group sequence analysis software package (Genetics Computer Group 1991). The cloned PKX rDNA sequence was compared by sequence alignment with 5 other complete myxosporean SSU IRNA genes that originated from Henneguya sp., H. doori, Myxobolus sp. 1, Myxobolus sp. 2, and
Myxidium sp. Their accession numbers in the GenBank were U13926, U38549, U13928, U13930 and U13929 respectively.

Phylogenetic studies. The phylogenetic analysis was carried out by using the MUST package version 1.0 (Philippe 1993), the PHYLIP package version 3.5 (Felsenstein 1993), and the fastDNAml program version 1.0 (Olsen et al. 1994). For the phylogenetic reconstruction, only regions where unambiguous alignment could be achieved were used, yielding 1215 aligned positions. Trees were built using each of the following methods: distance (Saitou \& Nei 1987), parsimony and maximum likelihood (Felsenstein 1981). In the first case, the distances were corrected for multiple substitutions using Kimura's 2-parameter method (1980). The robustness of the phylogenetic inference was tested by the bootstrap approach (Felsenstein 1985) for distance (1000 replicates) and parsimony (100 replicates) analysis using the MUST and PHYLIP packages respectively. The relative rate test (Sarich \& Wilson 1967) was used in order to detect the fast-evolving species

\section{RESULTS}

DNA from EPKC was prepared and PCR amplification of SSU rRNA gene using universal primers resulted in a single $1.8 \mathrm{~kb}$ product of the expected length. The sequence of the SSU rRNA gene was 1802 nucleotides Iong and was verified to be similar to that of myxosporean SSU rDNAs and different from that of rainbow trout SSU rDNA (R. Hedrick pers. comm.).

A preliminary neighbor-joining analysis of the SSU rRNA sequences was carried out in order to detect closely related species. A sample of 128 species providing a good representation of the genetic diversity of each phylum was constructed. We applied 3 tree reconstruction methods to this data set. On this tree (Fig. 1), the PKX was the sister group of the Myxozoa, but the bootstrap proportions (BP) for this node were not very high (56 and $63 \%$ ). This group constituted the sister group of all the triploblast metazoans, but with still smaller BP (34 and 50\%). In this analysis, Myxozoa was not the sister group of the nematodes (Smothers et al. 1994) or Polypodium hydriforme (Sidall et al. 1995). Since the Myxozoa and PKX appeared to have fastevolving SSU rRNA sequences, the long branches attraction phenomenon (Felsenstein 1985) could have generated an erroneous position for the Myxozoa. Therefore, a relative rate was performed (data not shown). Myxozoa and PKX were among the fast-evolving sequences together with some triploblast species (Mesozoa, some Platyhelminthes and Nematoda). When 52 species displaying the fastest-evolving sequences were removed, except those for Myxozoa 


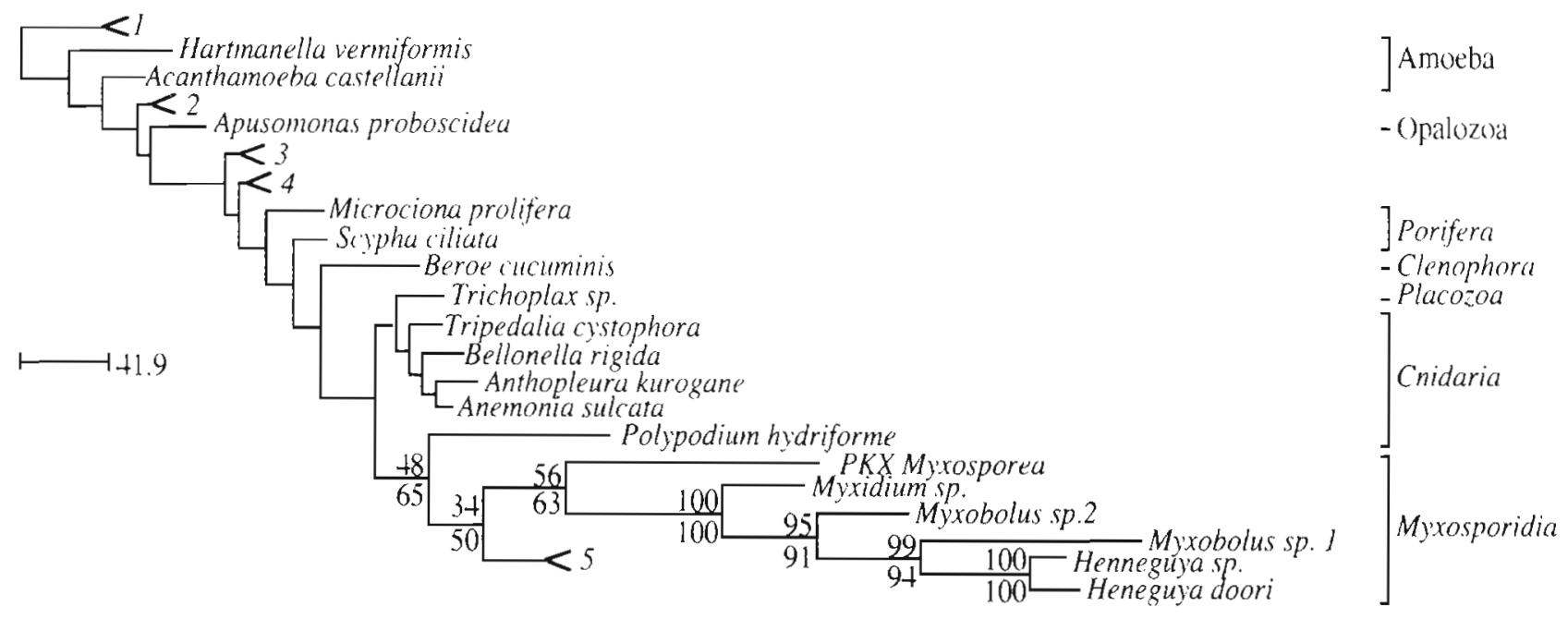

Fig. 1. Abbreviated phylogenetic position of the PKX parasite relative to 127 other eukaryotic species. Symbol $(<)$ groups the following together: (1) outgroup, nucleomorph of Chloroarachniophyta and Pelobionta; (2) Cryptophyta, Chlorobionta, Rhodobionta, Haptophyta, Haplosporida, Plasmodiophorida, filose amoeba, Alveolata and Stramenopiles; (3) Fungi; (4) choanoflagellates; and (5) triploblasts, encompassing 12,45,10,7 and 36 species respectively. The tree was constructed with parsimony on 1165 unambiguously aligned positions using the PHYLIP program. The branch lengths are proportionate to the estimated number of substitutions (ACCTRAN option). The BP values are indicated on the left of each node, upper position when computed with the parsimony method and lower position when computed with the distance method. BP values are indicated only in the area of emergence of the PKX sequence

representatives and PKX, the phylogenetic inference was completely different than in Fig. 1 (not shown), but PKX was again a sister group of Myxozoa with better statistical support (BP of 89 and $97 \%$ ).

\section{DISCUSSION}

The PKX SSU rRNA sequence presented here is the second nucleotidic sequence reported from a PKX parasite. The first one encoded a parasitic antigen (Saulnier et al. 1996) that unfortunately could not be used for further phylogenetic studies since no substantial homology with previously reported sequences was displayed. The phylogenetic position of PKX as a sister group of Myxozoa was observed with all tree reconstruction methods used, whatever the species sampling used for comparison. Such a result could be considered as reliable, even if one must remain cautious, because since both PKX and Myxozoa were found to evolve very quickly, their sequences could group together due to the long branch attraction. However, PKX never clustered with another fast-evolving species such as Dicyema, Caenorhabditis or the nucleomorph of Chlorarachnion.

With respect to the position of Myxozod, no coherent phylogenetic picture was yielded, using either different sequence samplings, by excluding fast-evolving sequences found in this study in order to improve phylogenetic inference (Philippe et al. 1994), or the maximum likelihood method, which is currently considered to be among the less sensitive ones (Hasegawa et al. 1991), because both triploblasts and myxosporea all evolve very fast. Nevertheless, the fact that the position of PKX as a sister group of Myxozoa was found insensitive to species sampling reinforced reliability (Lecointre et al. 1993) as did the fact that numerous species were used to reduce the impact of species sampling (Philippe \& Douzery 1994) and to break long branches as much as possible (Hendy \& Penny 1989).

Sequencing other well-conserved genes such as the elongation factor EF1- $\alpha$ (Baldauf \& Palmer 1993, Kamaishi et al. 1996) seems thus necessary to definitively settle the position of Myxozoa within the Metazoa. Furthermore, since ultrastructural studies have pointed out the similarities between PKX and the presporogonic stage of myxosporeans belonging to the Sphaerospora genus (Kent \& Hedrick 1985, Voronin 1993), it will be of particular interest to confirm or infirm at the molecular level their kinship by determination of their SSU rRNA genes in order to propose a species denomination for PKX related to or not related to this genus.

Acknowledgements. This research was supported by the European community (contract AIR2CT93-1570) and Sanofi Santé Nutrition Animale. We are grateful to P. Vende for the sequencing of the gene and to the staff of the experimental fishery facilities for the maintainance of PKD-infected fish. We thank Miklos Müller for critically reading the manuscript. 


\section{LITERATURE CITED}

Baldauf SL, Palmer JD (1993) Animals and fungi are each other's closest relatives: congruent evidence from multiple proteins. Proc Natl Acad Sci USA 90:11558-11562

D'Silva J, Mulcahy MF, de Kinkelin P (1984) Experimental transmission of proliferative kidney disease in rainbow trout, Salmo gairdneri Richardson. J Fish Dis 7:236-240

Felsenstein J (1981) Evolutionary trees from DNA sequences: a maximum likelihood approach. J Mol Evol 17:378-386

Felsenstein J (1985) Confidence limits on phylogenies: an approach using the bootstrap. Evolution 40(4):783-791

Felsenstein J (1993) PHYLTP manual version 35. University Herbarium. University of California, Berkeley, CA

Ferguson HW, Adair C (1977) Protozoa associated with proliferative kidney disease in rainbow trout, Salmo gairdneri Vet Rec 100:158-159

Ferguson HW, Needham EA (1978) Proliferative kidney disease in raibow trout, Salmo gairdneri Richardson. J Fish Dis 1:91-108

Genetics Computer Group (GCG) (1991) Program manual for the GCG package, Version 7, April 1991. GCG, Madison, WI

Grassé PP. Lavette A (1978) La myxosporidie Sphaeromyxa sabrazesi et le nouvel embranchement des Myxozoaires (Myxozoa). Recherches sur l'état pluricellulaire primitif et considérations phylogénétiques. Ann Sci Nat Zool Paris 20: $193-285$

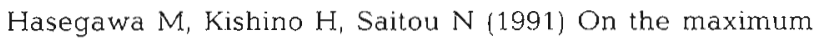
likelihood method in molecular phylogenetics. J Mol Evol 33:443-445

Hedrick RP, Mac Connell E, de Kinkelin P (1993) Proliferative kidney disease of salmonid fish. In: Faisal M, Hetrick FM (eds) Annual review of fish diseases, Vol IIl. Pergamon Press, Oxford, p 277-290

Hendy MD, Penny D (1989) A framework for the quantitative study of evolutionary trees. Syst Zool 38(4):297-309

Jackson DP, Hayden JD, Quirke P (1991) Extraction of nucleic acid from fresh and archival material. In: McPherson MJ, Quirke P, Taylor GR (eds) PCR: a practical approach. IRL Press at Oxford University Press, Oxford, p 29-49

Kamaishi T, Hashimoto T, Nakamura Y, Nakamura F, Murata S, Okasa N, Okamoto K, Shimuzu M, Hasegawa M (1996) Protein phylogeny of translation elongation EF $1 \alpha$ suggests microsporidians are extremely ancient eucaryotes. J Mol Evol 43:257-263

Kent ML, Hedrick RP (1985) PKX, the causative agent of proliferative kidney disease (PKD) in Pacific salmonid fishes and its affinities with the Myxozod. J Protozool 33:254-260

Kimura M (1980) A simple method for estimating evolutionary rate of base substitutions through comparative studies of nucleotide sequences J Mol Evol 16:111-120

Lecointre G. Philippe H, Lè HLV, Le Guyader H (1993) Spe-

Editorial responsibility: Wolfgang Körting.

Hannover, Germany cies sampling has a major impact on phylogenetic inference. Mol Phylogenet Evol 2(3):205-224

Lom J, Arthur JR (1989) A guideline for the preparation of species descriptions in Myxosporea. J Fish Dis 12:151-156

McCombie WR, Heiner C, Kelley JM, Fitzgerald MG. Gocayne JD (1992) Rapid and reliable fluorescent cycle sequencing of double-stranded templates. DNA Seq 2: $289-296$

Medlin L, Elwood HJ, Stickel S, Sogin ML (1988) The characterization of enzymatically amplified eukaryotic 16S-like rRNA-coding regions. Gene 71:491-499

Olsen GJ, Matsuda H, Hagstrom R, Overbeek R (1994) fastDNAml: a tool for construction of phylogenetic trees of DNA sequences using maximum likelihood. Comput Appl Biosci 10:42-48

Philippe H (1993) MUST: a computer package of management utilities for sequences and trees. Nucleic Acids Res 21(22):5264-5272

Philippe H., Douzery E (1994) The pitfalls of molecular phylogeny based on four species as illustrated by the Cetacea/ Artiodactyla relationships. J Mamm Evol 2:134-152

Philippe $\mathrm{H}$, Chenuil A, Adoutte A (1994) Can the cambrian explosion be inferred through molecular phylogeny? Development 120(Suppl): 15-25

Saitou N, Nei M (1987) The neighbor-joining method: a new method for reconstructing phylogenetic trees. Mol Biol Evol $4(4): 416-436$

Sarich VM. Wilson AC (1967) Immunological time scale for hominid evolution. Science 158:1200-1203

Saulnier D, de Kinkelin P (1996) Antigenic and biochemical study of $\mathrm{PKX}$, the myxosporean causative agent of proliferative kidney disease of salmonid fish. Dis Aquat Org 27:1.03-114

Saulnier D, Brémont $M$ de Kinkelin $P$ (1996) Cloning, sequencing and expression of a cDNA encoding an antigen from the myxosporean parasite causing the proliferative kidney disease of salmonid fish. Mol Biochem Parasitol 83:153-161

Seagrave C, Bucke D, Alderman DJ (1980) The causative agent of proliferative kidney disease may be a member of the Haplosporidia. In: Ahne W (ed) Fish diseases. Third COPRAQ Session. Springer-Verlag, Berlin, p 174-181

Sidall ME, Martin DS, Bridge D, Desser SS, Cone DK (1995) The demise of a phylum of protists: phylogeny of Myxozoa and other parasitic cnidaria. J Parasitol 81(6):961-967

Smothers F, von Dohlen CD, Smith LH Jr, Spall RD (1994) Molecular evidence that the myxozoan protists are metazoans. Science 265:1719-1721

Voronin VN (1993) PKX like organism in common carp during swimbladder inflammation: further evidence of an association with the myxosporean Sphaerospora renicula. Bull Eur Assoc Fish Pathol 13(4):127-129

Submitted: October 10,1997; Accepted: January 18, 1999

Proofs received from author(s): May 21, 1999 